\title{
Ligation versus Clipping of the Appendicular Stump in Laparoscopic Appendectomy
}

\author{
AHMED A. DARWISH, M.D.; IBRAHIM M. ABDEL MAKSOUD, M.D. and MOHAMED S.F. ZAEMA, M.Sc. \\ The Department of General Surgery, Faculty of Medicine, Ain Shams University
}

\begin{abstract}
Background: Appendectomy is the most common surgical procedure performed in general surgery. For almost a century, open appendectomy, first described by Charles McBurney in 1889, has remained the gold standard treatment for acute appendicitis. The introduction of laparoscopic surgery has dramatically changed the field of surgery and laparoscopic surgery has been widely used as a minimally invasive surgery.

Aim of Study: Comparative evaluation of intra-corporeal ligation versus titanium clip application as methods of securing the appendicular stump. As regard safety, simplicity, competence, surgical technique, operative time, hospital stay and post-operative morbidity.

Patients and Methods: This study was conducted to evaluate the results of the Intracorporeal ligation versus Titanium clips application in securing the appendicular stump in regarding operative time, operative findings, post-operative complications, hospital stay and return of the patients to their normal daily activities.

Results: The overall post-operative complications were different in the 2 group. The incidence of wound infection was less in clips group (0\% versus $10 \%)$. The mean hospital stay was shorter in clips group patients than ligation group patients (13.45 versus 18.95 hours). The mean time to return to normal activities was shorter in titanium clips patients (5.45 days versus 6.30 days). The use of laparoscope in suspected appendicitis is better than the open method especially in equivocal cases to reach an exact diagnosis. We must not hesitate to convert laparoscopic appendectomy to open appendectomy for the sake and safety of the patient.

Conclusion: Both methods of intracorporeal ligation and clip application are cost effective in securing the appendicular stump. Titanium clip application is more easy to the surgeon, more time saving during the operation and less post-operative stay in the hospital. The only limitation of the clip application is the wider diameter of the base of the appendix beyond the large titanium clip in these cases intra-corporeal ligation is a safe and cheap alternative.
\end{abstract}

Key Words: Laparoscopic appendectomy-Ulcerative colitis - Ligation-Clipping.

Correspondence to: Dr. Mohamed S.F. Zaema, E-Mail: mohammedzaema@gmail.com

\section{Introduction}

THE appendix is a small tube-shaped pouch attached to the caecum and located in the lower right side of abdomen [1].

Appendicitis was first recognized as a disease in the sixteenth century and was called perityphlitis [2].

Appendicitis is the most common intraabdominal condition requiring emergency surgery. Appendectomy continues to be one of the commonest procedures in general surgery, accounts for approximately $1 \%$ of all surgical operation [3]

The first appendectomy was performed in 1736 by Claudius Amyand, Surgeon of St. Georges Hospital, London, UK [4] . McBurney in 1889 described the clinical features of acute appendicitis. Open appendectomy has been the standard surgical treatment since the last century [2]

Diagnosis is founded upon well-recognized signs, symptoms as well as physician's practice. The signs \& symptoms most prognostic of acute appendicitis is pain in Right Lower Quadrant (RLQ) or pain around umbilicus and then transferring to RLQ presenting along with fever, nausea and vomiting. On abdominal examination there will be rigidity, tenderness and rebound tenderness in right iliac fossa [5].

The reported incidence of acute appendicitis has increased over the last few decades potentially due to the increased use of CT imaging, with the rate of complicated appendicitis representing $25 \%$ of all cases [6].

Several diseases such as pelvic inflammatory disease, endometriosis, ovarian cysts, ectopic preg- 
nancy, cholecystitis and colonic perforation may mimic acute appendicitis so proper imaging is mandatory in diagnosis of acute appendicitis [7]

The introduction of laparoscopic surgery has dramatically changed the field of surgery. With improvement in the equipment and increasing clinical experience it is possible to perform almost any kind of procedure under laparoscopic visualization [8] . Laparoscopic appendectomy was first reported by the gynaecologist Kurt Semm in 1982 [9].

The laparoscopic approach allows a full exploration of the peritoneal cavity, thus representing an important diagnostic tool in case there is only suspicion of acute appendicitis [7]. Complicated Appendicitis (CA) defined as gangrenous or perforated appendicitis with or without peritonitis has been increasingly managed laparoscopically. $67 \%$ of cases of CA performed laparoscopically in 2011 in the USA [6]. An accepted negative appendicectomy rate for presumed appendicitis ranges from $15 \%$ to $20 \%$, even higher in women of childbearing age from $20 \%$ to $30 \%$ [10].

Society of American Gastrointestinal and Endoscopic Surgeons (SAGES) strongly recommends LA only for female patients of child-bearing age because the advantages of minimal invasive surgery such as shorter length of hospital stay, better cosmetic appearance, faster recovery and return to normal activities and less postoperative pain in patients with uncomplicated appendicitis in particular [11]

The European Association of Endoscopic Surgeons (EAES) has recently released guidelines on appendectomy that clearly favour the laparoscopic approach [12].

Criticism of LA includes increased operative cost, primarily due to the use of disposable laparoscopic instruments, increased operation time, and concerns about a higher incidence of intraabdominal abscesses, particularly after perforated appendicitis [13].

\section{Aim of the work:}

Comparative evaluation of intra-corporeal ligation versus titanium clip application as methods of securing the appendicular stump. As regard safety, simplicity, competence, surgical technique, operative time, hospital stay and post-operative morbidity.

\section{Patients and Methods}

This study was conducted in Ain Shams Faculty of Medicine, Ain Shams University Hospitals, General Surgery Department from November 2019 to April 2020.

The study was conducted on 40 patients diagnosed with acute appendicitis.

Inclusion criteria: All cases of acute appendicitis that were subjected to laparoscopic appendectomy were included in the study.

Exclusion criteria: Patients in whom laparoscopic appendectomy has to be converted into open procedure. Appendicular mass which was diagnosed either by ultrasound or by examination under anesthesia. Cases with perforation at the base.

The patients were randomly allocated into two groups 20 patients each:

Ligation group, the patients were operated by Laparoscopic Appendectomy, (LA) and the appendicular stump is secured by intra-corporeal ligation.

Titanium clip group, the patients were operated by Laparoscopic Appendectomy, (LA) and the appendicular stump is secured by application of titanium clips.

All patients were followed-up for 6 months postoperatively and were subjected to: History taking. Clinical examination including PR and PV. Laboratory investigations: $\mathrm{CBC}$. Na and $\mathrm{K}$ in markedly dehydrated patients. Urine analysis in suspected cases of urinary tract infection. Radiological investigation: Ultrasound (abdomino-pelvic).

Ultrasonography was routinely done for all patients to help in confirmation of the clinical diagnosis and also helps in the diagnosis of complications like mass which was considered exclusion criteria; CT with oral and intravenous contrast was requested in case of suspicion of complications that were not diagnosed definitely by ultrasound.

Patients were fully informed about the risks and benefits of the 2 procedures. Informed consent was obtained from every patient.

Markedly dehydrated patients had fluid resuscitation and Foley catheter to ensure adequate urine output. Any electrolyte deficiencies were corrected prior to the induction of general anaesthesia.

Prior to the surgical incisions, all the patients received a standard regimen of intravenous antibi- 
otics $(1.5 \mathrm{gm}$ of ampicillin, sulbactam and $500 \mathrm{mg}$ of Metronidazole).

\section{Criteria of discharge of the patient from the hospital:}

Absence of fever. Good tolerance of oral diet. Removal of the drain if was inserted. The patients were followed-up for 6 months.

\section{Technique of laparoscopic appendectomy:}

The patient was placed supine in a $15^{\circ}$ Trendelenberg position with both arms tucked. Rotation to the left was done. The surgeon stood on the patient's left side. The camera man stood on the surgeon's left side. The monitor was on the patient's right side. After the induction of general anaesthesia, a urinary catheter and a nasogastric tube were placed. A pneumoperitoneum was created in standard fashion, using either the Veress needle technique or the open technique according to the surgeon preference. The first trocar $(10 \mathrm{~mm})$ was introduced at the lower margin of the umbilicus. The intraperitoneal pressure was set to be $14 \mathrm{mmHg}$. Laparoscopy was then performed with "30" angle viewing laparoscope to ensure the clinical diagnosis and identify the position of the appendix so as to determine the best site of insertion of the other trocars. A second $10 \mathrm{~mm}$ suprapubic trocar was inserted. A third trocar was inserted in the left iliac fossa. In 2 cases 4 th trocar in the right upper quadrant was inserted to facilitate dissection of retrocecal appendix.

After insertion of the ports, a quick diagnostic laparoscopy was performed in order to confirm the diagnosis and assess other pathologies. The surgeon's left hand held a Babcock grasper to retract the caecum and subsequently expose the appendix. Cautery scissors were used to incise the retroperitoneal attachments of the caecum in difficult cases. This will expose the mesoappendix and make it easy to create a window mesoappendix close to the base. The rest of the technique will be the same as in open appendectomy where we apply a tie in the mesoappendix and one of the two techniques in the appendicular stump either a ligation or a titanium clip to secure the stump of the appendix.

After transection the appendicular stump mucosa was carefully cauterized. The appendix was pulled into the umbilical port and withdrawn with the whole port or was placed in an impermeable retrieval bag before its removal. Irrigation and insertion of a drain were done only in indicated cases. Trocars were removed under direct vision.
Fascia at the 10-mm trocar site was closed, and all wounds were closed primarily.

In patients with complicated appendicitis, antibiotics were not discontinued but were modified according to the culture results and continued for 7 to 10 days till the patient was afebrile.

Patients were given sips of water after passing flatus or faeces or after hearing intestinal sounds to avoid paralytic ileus from early introduction of food or liquids.

Post-operatively, all patients received analgesics in the form of NSAIDs for 24 hours, then analgesics were given upon the patient request.

The discharge criteria are met once the patients were afebrile, with audible bowel sounds and were able to tolerate a liquid diet and oral analgesia. The specimens were sent for pathology for assessing pathological diagnosis.

The comparison between the 2 groups was in the following criteria: Intraoperative: Operative time (from skin incision to wound closure), intraoperative findings (normal, gangrenous, inflamed or perforated), intraoperative complications, associated pathology and its management. Postoperative: Early post-operative morbidity up to 4 weeks including wound infection, late postoperative complications up to 6 months including (pelvic abscess, port site hernia and adhesive intestinal obstruction), post-operative hospital stay and time needed to return to work.

\section{Statistical analysis of the data:}

Data were fed to the computer and analyzed using IBM SPSS software package version 20.0. (Armonk, NY: IBM Corp) qualitative data were described using number and percent. The Kolmogorov-Smirnov test was used to verify the normality of distribution quantitative data were described using range (minimum and maximum), mean, standard deviation and median. Significance of the obtained results was judged at the 5\% level.

The used tests were: Chi-square test: For categorical variables, to compare between different groups. Fisher's Exact or Monte Carlo correction: Correction for chi-square when more than $20 \%$ of the cells have expected count less than 5. Student $t$-test: For normally distributed quantitative variables, to compare between two studied groups. Mann Whitney test: For abnormally distributed quantitative variables, to compare between two studied groups. 
Cases:

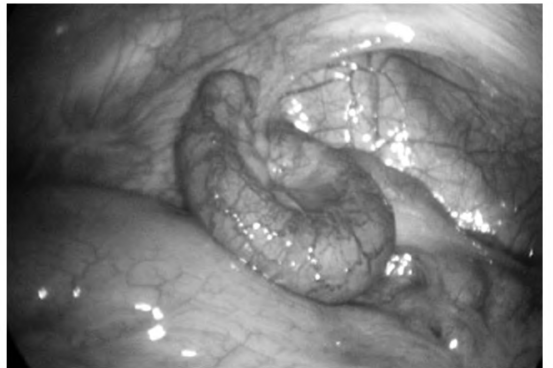

Fig. (1): A case of acute catarrhal appendicitis.

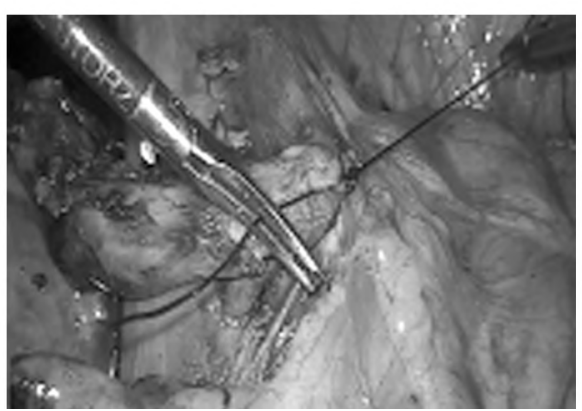

Fig. (4): Intracorporeal ligation of the appendicular stump.

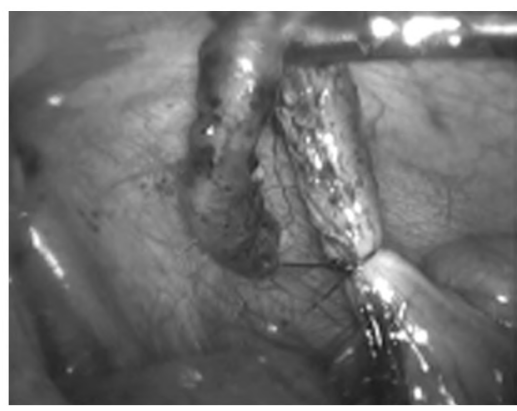

Fig. (7): Ligation of the stump of the appendix.

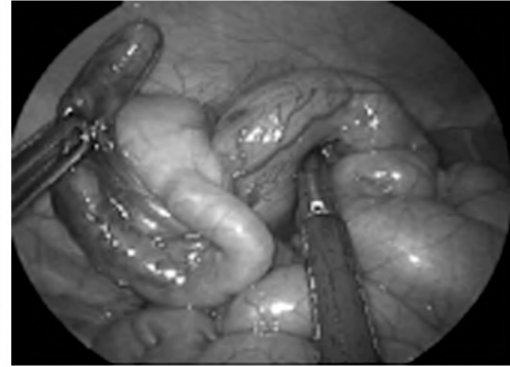

Fig. (2): A case of acute suppurative appendicitis.

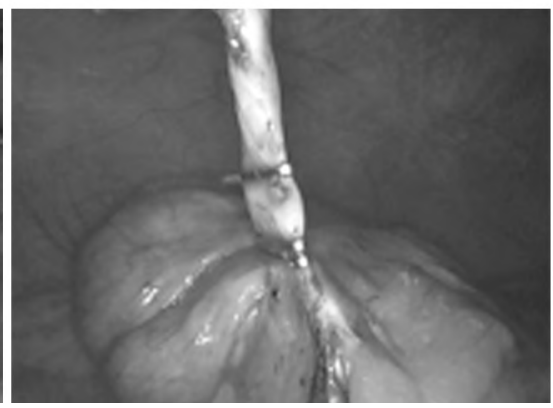

Fig. (5): Titanium clips application on the stump of the appendix.

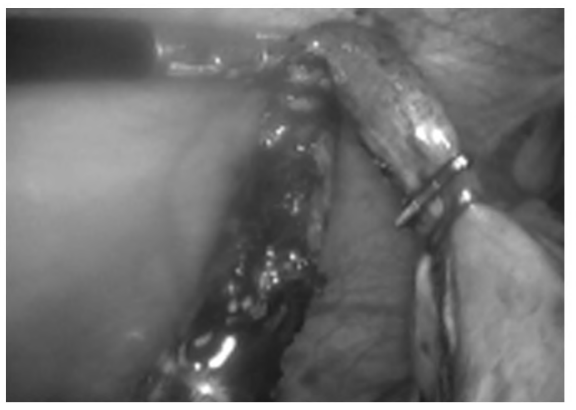

Fig. (8): Titanium clips application on the stump of the appendix.

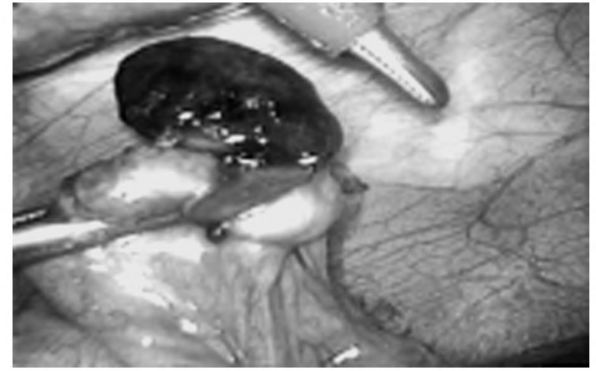

Fig. (3): A case of gangrenous appendicitis.

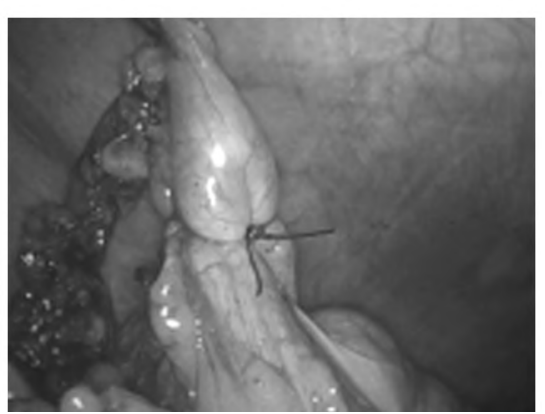

Fig. (6): Ligation of the stump of the appendix.

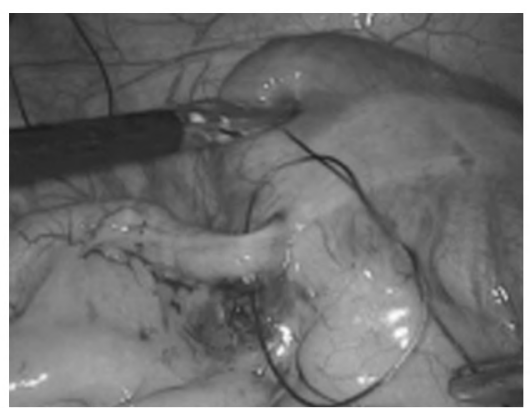

Fig. (9): Ligation of the base of the appendix.

\section{Results}

Table (1): Comparison between the two studied groups according to age (years) and sex.

\begin{tabular}{lccccc}
\hline & $\begin{array}{c}\text { Intracorporeal } \\
\text { ligation group } \\
\text { No.=20 }\end{array}$ & $\begin{array}{c}\text { Titanium } \\
\text { clips group } \\
\text { No.=20 }\end{array}$ & $\begin{array}{c}\text { Test } \\
\text { value }\end{array}$ & $\begin{array}{c}p \text { - } \\
\text { value }\end{array}$ & Sig. \\
\hline $\begin{array}{l}\text { Age: } \\
\text { Mean + SD } \\
\text { Range }\end{array}$ & $26.00 \pm 7.11$ & $25.10 \pm 5.57$ & $0.446 \bullet$ & 0.658 & NS \\
Sex: & $13-40$ & $16-35$ & & & \\
Female & $12(60.0 \%)$ & $11(55.0 \%)$ & $0.102 *$ & 0.749 & NS \\
Male & $8(40.0 \%)$ & $9(45.0 \%)$ & & & \\
\hline
\end{tabular}

$p$-value $>0.05$ : Non significant (NS).

$p$-value $<0.05$ : Significant $(\mathrm{S})$.

$p$-value <0.01: Highly significant (HS).

*: Chi-square test.

•: Independent $t$-test.
Table (2): Comparison between the two studied groups according to intraoperative findings.

\begin{tabular}{|c|c|c|c|c|c|c|c|}
\hline & \multicolumn{2}{|c|}{$\begin{array}{l}\text { Intracorporeal } \\
\text { ligation group }\end{array}$} & \multirow{2}{*}{\multicolumn{3}{|c|}{$\begin{array}{l}\begin{array}{l}\text { Titanium } \\
\text { clips group Test } \\
\\
\text { value* }\end{array}\end{array}$}} & \multirow{2}{*}{$\begin{array}{c}p- \\
\text { value }\end{array}$} & \multirow{2}{*}{ Sig. } \\
\hline & No. & $\%$ & & & & & \\
\hline \multicolumn{8}{|l|}{$\begin{array}{l}\text { Condition of } \\
\text { the base. }\end{array}$} \\
\hline Normal & 13 & 65.0 & 12 & 60.0 & 0.107 & 0.744 & NS \\
\hline Edematous & 7 & 35.0 & 8 & 40.0 & & & \\
\hline \multicolumn{8}{|c|}{$\begin{array}{l}\text { Gross pathology of } \\
\text { the appendix: }\end{array}$} \\
\hline Normal & 2 & 10.0 & 1 & 5.0 & 0.392 & 0.942 & NS \\
\hline Suppurative & 8 & 40.0 & 9 & 45.0 & & & \\
\hline Catarrhal & 9 & 45.0 & 9 & 45.0 & & & \\
\hline Gangrenous & 1 & 5.0 & 1 & 5.0 & & & \\
\hline
\end{tabular}

$p$-value $>0.05$ : Non significant (NS).

$p$-value $<0.05$ : Significant $(\mathrm{S})$

$p$-value <0.01: Highly significant (HS).

*: Chi-square test. 
Table (3): Comparison between the two studied groups according to the operative time, post-operative hospital stay and return to work.

\begin{tabular}{|c|c|c|c|c|}
\hline & $\begin{array}{c}\text { Intracorporeal } \\
\text { ligation group } \\
\text { No. }=20\end{array}$ & $\begin{array}{c}\text { Titanium } \\
\text { clips group } \\
\text { No. }=20\end{array}$ & $\begin{array}{c}\text { Test } \\
\text { value }\end{array}$ & $\begin{array}{c}p- \\
\text { value }\end{array}$ Sig \\
\hline \multicolumn{5}{|c|}{ Operative time (min.): } \\
\hline Mean \pm SD & $55.62 \pm 6.04$ & $46.44 \pm 6.83$ & 4.504 & $0.000 \mathrm{HS}$ \\
\hline Range & $45.55-67.46$ & $37.16-62.59$ & & \\
\hline \multicolumn{5}{|c|}{ Hospital stay (hours): } \\
\hline Mean \pm SD & $18.95 \pm 3.83$ & $13.45 \pm 3.52$ & 4.729 & $0.000 \mathrm{HS}$ \\
\hline Range & $12-25$ & $9-20$ & & \\
\hline \multicolumn{5}{|c|}{ Return to work (days): } \\
\hline Mean \pm SD & $6.30 \pm 1.78$ & $5.45 \pm 1.50$ & $1.631 \bullet$ & • $0.111 \mathrm{HS}$ \\
\hline Range & $4-9$ & $4-9$ & & \\
\hline
\end{tabular}

$p$-value $>0.05$ : Non significant (NS).

$p$-value $<0.05$ : Significant $(\mathrm{S})$.

$p$-value <0.01: Highly significant (HS).

$\bullet:$ Independent $t$-test.

Table (4): Comparison between the two studied groups according to post-operative complications.

\begin{tabular}{|c|c|c|c|c|c|}
\hline Complications & $\begin{array}{c}\text { Intracorporeal } \\
\text { ligation group } \\
\text { No. }=20\end{array}$ & $\begin{array}{l}\text { Titanium } \\
\text { clips group } \\
\text { No.=20 }\end{array}$ & $\begin{array}{c}\text { Test } \\
\text { value }\end{array}$ & $\begin{array}{c}p- \\
\text { value }\end{array}$ & Sig. \\
\hline $\begin{array}{l}\text { Intestinal injury } \\
\text { Absent }\end{array}$ & $20(100.0 \%)$ & $20(100.0 \%)$ & NA & NA & NA \\
\hline $\begin{array}{l}\text { Ileus: } \\
\text { Absent } \\
\text { Present }\end{array}$ & $\begin{array}{ll}18 & (90.0 \%) \\
2 & (10.0 \%)\end{array}$ & $\begin{array}{ll}20 & (100.0 \%) \\
0 & (0.0 \%)\end{array}$ & $2.105^{*}$ & 0.147 & NS \\
\hline $\begin{array}{l}\text { Pelvic abscess: } \\
\quad \text { Absent }\end{array}$ & $20(100.0 \%)$ & $20(100.0 \%)$ & NA & NA & NA \\
\hline $\begin{array}{l}\text { Port site infectio } \\
\text { Absent } \\
\text { Present }\end{array}$ & $\begin{array}{ll}18 & (90.0 \%) \\
2 & (10.0 \%)\end{array}$ & $\begin{array}{l}20(100.0 \%) \\
0 \quad(0.0 \%)\end{array}$ & $0.360^{*}$ & 0.548 & NS \\
\hline $\begin{array}{l}\text { Failure of techni } \\
\text { Absent }\end{array}$ & $20(100.0 \%)$ & $20(100.0 \%)$ & NA & NA & NA \\
\hline $\begin{array}{l}\text { Re-admission: } \\
\text { Absent }\end{array}$ & $20(100.0 \%)$ & $20(100.0 \%)$ & NA & NA & NA \\
\hline $\begin{array}{l}\text { Re-operation: } \\
\text { Absent }\end{array}$ & $20(100.0 \%)$ & $20(100.0 \%)$ & NA & NA & NA \\
\hline $\begin{array}{l}\text { Port site hernia } \\
\text { Absent }\end{array}$ & $20(100.0 \%)$ & $20(100.0 \%)$ & NA & NA & NA \\
\hline $\begin{array}{l}\text { Adhesions: } \\
\text { Absent }\end{array}$ & $20(100.0 \%)$ & $20(100.0 \%)$ & NA & NA & NA \\
\hline
\end{tabular}

\section{Discussion}

Approximately $6 \%$ of the population develop appendicitis in their life time, with peak incidence between the ages of 10 and 30 years, thus making appendectomy the most frequently performed abdominal operation [14].

The treatment of acute appendicitis remained essentially unchanged since its first description by
Charles Mcburney in 1889. Appendectomy by Mcburney's incision remained the procedure of choice for nearly a century until 1983 when Kurt Semm offered an alternative, "laparoscopic appendectomy", but as Mcburney's operation is well tolerated with less co-morbidity the benefits of laparoscopic appendectomy have been difficult to establish [15]

Several authors proposed that the new technique of laparoscopic appendectomy should be the preferred treatment for acute appendicitis. Laparoscopic cholecystectomy is now considered a standard method of performing cholecystectomy and has mostly replaced the old method throughout the world, while appendectomy has yet to achieve such popularity [15]

The putative advantages of the laparoscopic approach are quicker and less painful recovery, fewer post-operative complications and better cosmoses. It allows better assessment of other intra-abdominal pathologies. But because of shortage of laparoscopic sets in some hospitals, laparoscopic appendectomy is not practiced widely [16]

Laparoscopic appendectomy has emerged as a safe procedure, and its potential advantages of shorter hospital stay, early mobilization, early return of bowel function, acceptable complication rate along with the recent enthusiasm of minimally invasive surgery, has led some authors to advocate this approach as the procedure of choice for uncomplicated appendicitis [17].

Clear and magnified visions of appendix with more space to manoeuvre through a small hole like incision are great advantages of laparoscopic surgery. Some surgeons with equal safety and ease in OA do "button hole" surgery. Hence regarding incision any advantage to LA is likely to be small and difficult to prove [18] .

The popularity of laparoscopic appendectomy is increasing among surgeons by time. The advantages of laparoscopic surgery such as, shorter recovery, less post-operative pain and better cosmetic results are strongly present in laparoscopic appendectomy [19]

The other major advantages of laparoscopic appendectomy are the diagnostic laparoscopy done before delivery of the appendix and lower rate of wound infection. Most cost studies have confirmed the higher cost of lap appendectomy in comparison to open appendectomy due to the cost of instruments during the procedure [20]. 
One of the important causes of higher cost is the instrument or tools used for securing the base. Different methods were used to secure the base during laparoscopic appendectomy including the use of Endo-GIA which is expensive, endo loop which is also relatively expensive and not available in many hospitals in our country. Other methods include metallic clips, polymeric clips and intracorporeal suture ligation which are less in cost Sahm and his colleagues confirmed, in their study that intra-corporeal ligation is a safe alternative for the expensive linear stapler or less expensive endoloop and show no significant difference in safety and efficacy [19]

In another study by Kiudelis and his colleagues, reported that intra-corporeal ligation is a safe method, and cheaper than endoloop technique. Compared with laparoscopic staplers end loops have an advantage as they are 6 to 12 times cheaper than stapling device, this was matching with our study since no major complications occurred with intra-corporeal ligation, the cost of course is less because we just used 1 ampoule of polyglactin 0 which might be used to close the port site as well in many cases, one other advantage of intracorporeal ligation is its applicability in all cases [21].

As commercially available titanium and absorbable clip can sustain a high degree of intraluminal pressure and cannot be displaced by a pressure of $300 \mathrm{mmHg}$, and are lower in cost, their use is acceptable for securing the appendicular stump like the cystic duct [22]

Rickert and co-workers, used a titanium double shanked clip in their study which was able to secure appendicular base up to $2 \mathrm{~cm}$ safely. This was different from our study because we used the ordinary medium large or large clip which cannot secure $2 \mathrm{~cm}$ diameter, the other major disadvantage reported by Rickert and his colleagues was the need for $12 \mathrm{~mm}$ port for introduction of clip applier. We do not consider it major drawback for using clips because most of surgeons will need this port for retrieval of the appendix; others use the telescope port for retrieval which is difficult and time consuming in some cases [23].

Our study matched with results of other studies, that using metallic clips for appendicular stump closure is safe and associated with less operative time in laparoscopic appendectomy. It also makes the procedure simpler and provides a useful alternative of intra-corporeal ligation [24]
We used monopolar diathermy with caution to cauterize the mucosa of the appendicular stump because the fluid emerging of the stump is potentially contaminated and this may be related to increased possibility of surgical site infection. This was inspired from a study by Ahmad and his colleagues, which revealed that cautery of appendicular mucosa is $100 \%$ effective in sterilization of the appendicular stump [25]

We did not use commercial endobag routinely for retrieval of the appendix because they are expensive and not available in our hospital, in most of cases we retrieved the appendix through $12 \mathrm{~mm}$ cannula to and extract them together to prevent contact between infected appendix and porte site but actually contact happens in some cases during manipulation. The cause of this was the large diameter of the appendix that made it difficult to be included inside the cannula. This explains the port site infection that happened in 2 cases out of $40(5 \%)$. Fortunately infections were mild and managed by simple drainage and a short course of antibiotic. In a study by Hansen and his colleagues, the incidence of port site infection was $2 \%$ which was lower than our study. Simply this can be attributed to endobags used in Hansen study. No doubt, the use of commercially available endobag will decrease the possibility of port site infection but its cost is the main obstacle for its routine use. The formation of endobag from sterilized glove is a good alternative with lower cost [26]

\section{Conclusion:}

Laparoscopic appendectomy is safe and feasible. Despite that the operating time for laparoscopic appendectomy is still higher than that for open procedure, laparoscopic approach had several advantages over open appendectomy in that, it has lesser incidence of wound infection, shorter hospital stay, less need for post-operative analgesia and faster return of patients to normal activities. Moreover, it is very useful in reaching an exact diagnosis in equivocal cases. We must convert laparoscopic procedure to open surgery when indicated for the safety of the patient. A larger further study to evaluate the cost, benefit of titanium clips application on the appendicular stump is recommended.

\section{References}

1- AGRESTA F., ANSALONI L., CATENA F., VERZA L. and PRANDO D.: Acute appendicitis: Position paper, WSES 2013. World Journal of Emergency Surgery, 9 (1): 26, 2014.

2- BEG M., FARIDI S., QAZI A. and SIDDIQUI F.: Laparoscopic appendectomy-comparison with open appendec- 
tomy with respect to surgical site infection. Pak J. Surg., 33 (2): 115-8, 2014.

3- SHARMA N., MISHRA M., TRIPATHI A. and RAI V.: Comparative study and outcome of open versus laparoscopic appendectomy: Case series of 60 patients. International Surgery Journal, 4 (9): 3129-35, 2017.

4- TALUKDER M., ALAM H., ALAM M., ANWAR R., IQBAL M. and CHOWDHURY H.: Outcome of Laparoscopic Versus Open Appendicectomy: An Experience from BIRDEM General Hospital. BIRDEM Medical Journal, 5 (3): pp. 13-7, 2015

5- DAL N., LIGHARI Q. and LAGHARI Z.: Laparoscopic and open appendectomy. Professional Medical Journal, 23 (11), 2016.

6- ATHANASIOU C., LOCKWOOD S. and MARKIDES G.: Systematic Review and Meta-Analysis of Laparoscopic Versus Open Appendicectomy in Adults with Complicated Appendicitis: An Update of the Literature. World Journal of Surgery, 41 (12): pp. 3083-99, 2017.

7- MINUTOLO V., LICCIARDELLO A., Di STEFANO B. ARENA M., ARENA G. and ANTONACCI V.: Outcomes and cost analysis of laparoscopic versus open appendectomy for treatment of acute appendicitis: 4-years' experience in a district hospital. BMC Surgery, 14 (1): p. 14, 2014.

8- KEHAGIAS I., KARAMANAKOS, PANAGIOTOPOULOS, PANAGOPOULOS K. and KALFARENTZOS F.: Laparoscopic versus open appendicectomy which way to go? World Journal of Gastroenterology: WJG, 14 (31), p. 4909, 2008.

9- SIDDIQUI S., SHAHI K. and KALA S.: A comparative study of laparoscopic surgery vs open surgery for interval appendicectomy. Paripex-indian Journal of Research, 7 (3), 2018.

10- KOLHAR B., LAMANI Y., SHEKHAR R. and SHANKAR G.: Outcomes of laparoscopic versus open appendectomy: A comparative study. International Surgery Journal, 4 (7): pp. 2185-8, 2017.

11-KOCATA_A., GÖNENÇ M., BOZKURT M., KARABULUT M., GEMICI E. and AL1 S H.: Comparison of open and laparoscopic appendectomy in uncomplicated appendicitis: A prospective randomized clinical trial. Ulus Travma Acil Cerrahi Derg., 19 (3): 200-4, 2013.

12- ALI S. and DEVANI R.: Laparoscopic verses open appendicectomy. International Surgery Journal, 2 (4): 5057, 2016.

13- DAI L. and SHUAI J.: Laparoscopic versus open appendectomy in adults and children: A meta-analysis of randomized controlled trials. United European gastroenterology journal, 5 (4), pp. 542-53, 2017.
14- KUMAR B., SAMAD A., KHANZADA T., LAGHARI M. and SHAIKH A.: Superiority of laparoscopic appendectomy over open appendectomy: The Hyderbad experience. Rawal Med. J., 33: 165-8, 2008.

15- PEISER J. and GREENBERG D.: Laparoscopic versus open appendectomy: Results of a retrospective comparison in an Israeli hospital. Isr. Med. Assoc. J., 4: 91-4, 2002.

16- SWEENEY K. and KEANE F.: Moving from open to laparoscopic appendectomy. BJS, 20: 257-8, 2003.

17- TRANOFF M., ATABEK U., GOODMAN M., ALEXANDER J., CHRZANOWSKI F. and MORTMAN K. Comparison of laparoscopic and open appendectomy. J. Soc. Laparoendos. Surg., 2: 153-8, 1998.

18- KAMAL M. and QURESHI K.: Laparoscopic versus open appendectomy. Pak J. Med. Res., 42, pp. 23-6, 2003.

19- SAHM M., KUBE R., SCHMIDT S., RITTER C., PROSS M. and LIPPERT H.: Current analysis of endoloops in appendiceal stump closure. Surg. Endosc., 25: 124-9, 2011.

20- SAFAVI A., LANGER M. and SKARSGARD E.D.: Endoloop versus endostapler closure of the appendiceal stump in pediatric laparoscopic appendectomy. Can. J. Surg., 55: 37-40, 2012.

21- KIUDELIS M., IGNATAVICIUS P., ZVINIENE K. and GRIZAS S.: Analysis of Intra-corporeal knotting with invaginating suture versus endoloops in appendicealstump closure. WideochirInne Tech. MaloInwazyjne, 8: 69-73, 2013.

22- DEANS G.T., WILSON M.S. and BROUGH W.A.: The ability of laparoscopic clips to with stand high intraluminal pressure. Arch. Surg., 130: 439-41, 1995.

23- RICKERT A., BÖNNINGHOFF R., POST S., WALZ M., RUNKEL N. and KIENLE P.: Appendix stump closure with titanium clips in laparoscopic appendectomy. Langenbecks Arch. Surg., 397: 327-31, 2012.

24- ATES M., DIRICAN A., INCE V., ARA C., ISIK B. and YILMAZ S.: Comparison of intra-corporeal knot-tying suture (polyglactin) and titanium endoclips inlaparoscopic appendiceal stump closure: A prospective randomized study. Surg. Laparosc. Endosc. Percutan. Tech., 22: 226$31,2012$.

25- AHMAD Q.A., SARWAR M.Z., LATIF W., CHATHA A.A. and WAHEED K.: Appendicular Stump Disinfection Using Povidone-iodine Swab Compared with Electrocautery; which one is more effective? J. Fatima Jinnah Medi University, 11, 2017.

26- HANSEN J., SMITHERS B., SCHACHE D., et al.: Laparoscopic versus open appendectomy. World J. Surg., 239: 43-52, 1996. 


\section{دراسة مقارنة بين ربط جذع الزائدة الدودية داخل الجسم

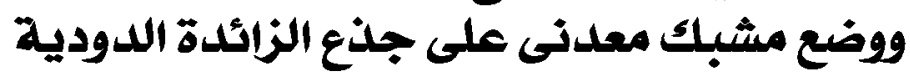

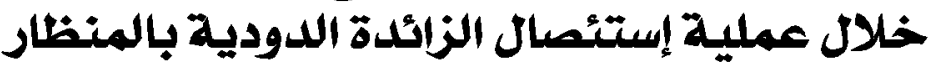

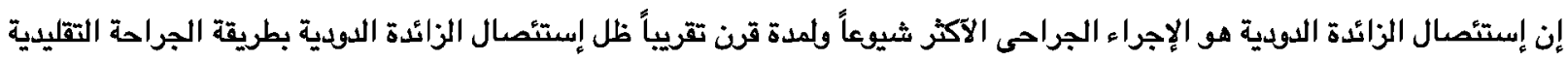

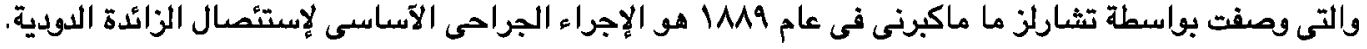
لقد آحدث إدخال المناظير تفيير كبير فى مجال الجراحة والتى إستخدمت منذ ذلك الحين على نطاق واسع فى إجراء الجراحات.

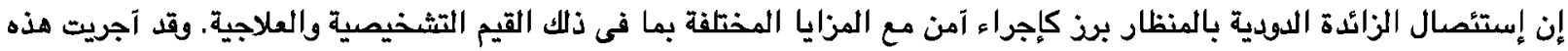

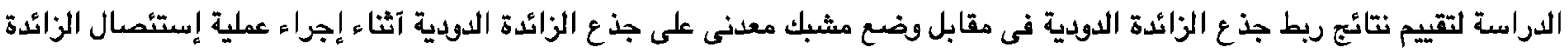

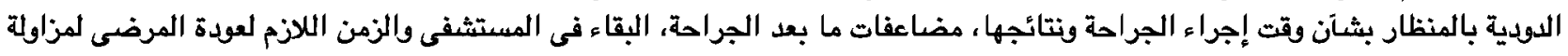
نشاطهم العادى.

آجريت الدراسة على •ع مريضاً تم تثخيص إصابتهم بإلتهاب الزائدة الدودية الحاد وتم إستقبال المرضى في قسم الطوارئ بمستشفيات

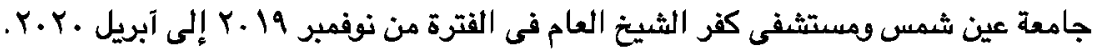

تم تقسيم المرضى بشّكل عشّوائى إلى مجموعتين لr مريضاً لكل منهما: • المجموعة الآولى هى مجموعة الربط، تم إجراء عملية جراحية للمرضى عن طريق إستئصال الزائدة الدودية بالمنظار وتم تآمين جذع الزائدة

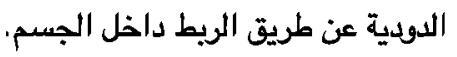
• المجموعة الثانية هي هجموعة مشبك التيتانيوم، تم إجراء عمليات جراحية للمرضى عن طريق إستئصال الزائدة الدودية بالمنظار وتم تآمين جذع الزائدة اللودية عن طريق وضع مشابك معدنية من التيتانيوم.

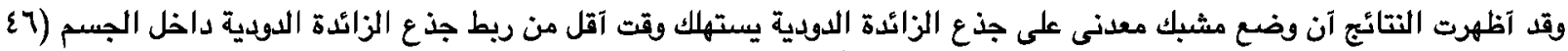

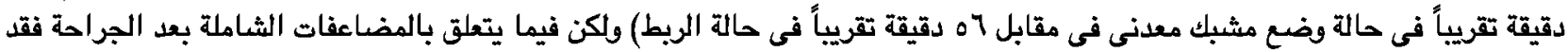

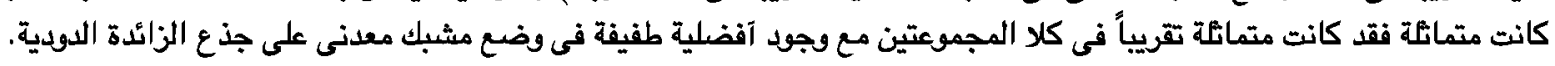
وقد آظهرت الدراسة آيضاً آن متوسط مدة الإقامة فى المستشفى آقصر فى المرضى الذين تم وضع مشبك معدنى لهم (ب ساعة تقريباً

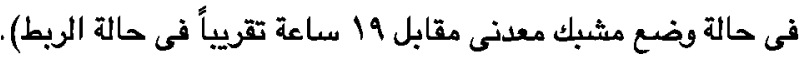
وآيضاً كانت العودة إلى الآنشطة العادية آقصر فى حالة وضع مشبك معدنى ولكن الفق لم يكن كبيراً فى هذا الجانب عن ربط جذع الزائدة الودية داخل الجسم.

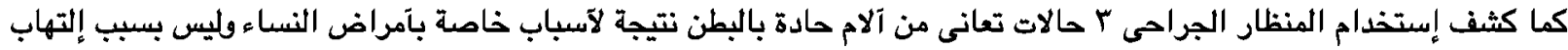

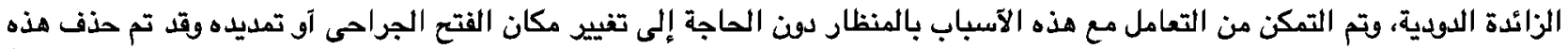

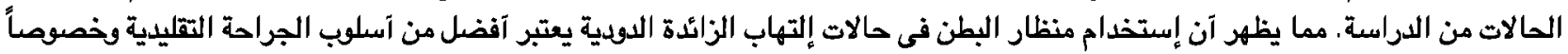

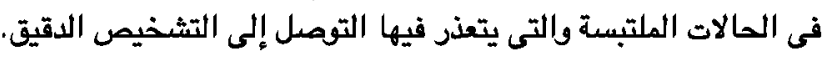

كما آنتا يجب آلا نتردد فى تحويل إستخدام المنظار الجراحى إلى الجراحة التقليدية من آجل سلامة المريض.

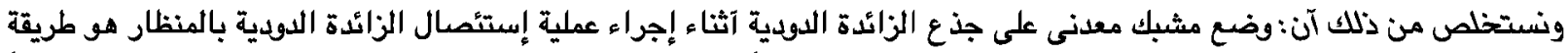

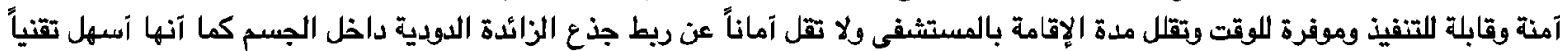
على الجراح. كما آنه ينصح بمزيد من الدراسة لتقييم التكاليف والإستفادة من إستئصال الزائدة الدودية بالمنظار الجراحى. 